Pteridines

Vol. 4, 1993, pp. 195-199

\title{
Are Disturbances of Zinc Metabolism in Human Immunodeficiency Virus Type 1 (HIV-1) Infection Caused By Immune Activation?
}

\author{
B. Melichar ${ }^{\# *}$, R. Zangerle ${ }^{\dagger}$, E. Artner-Dworzak ${ }^{\#}$, H. Wachter Z. $^{\ddagger}$ and D.Fuchs $\# . \ddagger \S$ \\ ${ }^{*}$ Institute of Medical Chemistry und Biochemistry, ${ }^{\dagger}$ AIDS-Unit, Dept. of Dermatology, \\ University of Innsbruck, A-6020 Innsbruck, Austria \\ ${ }^{\ddagger}$ Ludwig Boltzmann Institute of AIDS Research, A-6020 Innsbruck, Austria
}

(Received June 28, 1993)

\section{Summary}

The activation of the immune system is associated with profound alteration of zinc metabolism. In human immunodeficiency type 1 (HIV-1) infection serum zinc is frequently decreased. To investigate a potential role of immune system activation on urinary zinc wasting, we compared urinary zinc and neopterin levels in 52 patients with HIV-1 infection. In addition, serum zinc was studied in 25 of the patients. We confirmed earlier reports of decreased serum zinc levels in the patients. As expected, urinary neopterin was significantly increased in HIV-1 infection, the highest values being reached in AIDS patients. Urinary zinc concentrations were not statistically different between patients and controls. However, a positive correlation existed between urinary zinc and neopterin levels and between neopterin and zinc clearance coefficient in patients with more advanced stages of HIV infection. No correlation between serum zinc and urinary neopterin or urinary zinc was found. The data indicate that, in addition to malabsorption, chronic immune activation may contribute to the development of zinc deficiency by urinary zinc wasting.

Key words: Zinc, HIV-infection. Urinary excretion of zinc. Neopterin. Immune activation

\section{Introduction}

Zinc deficiency is common in human immunodeficiency virus type 1 (HIV-1) infection (1-4), and serum zinc was recently shown to predict prognosis (5). A decrease in serum or plasma zinc levels together with elevated urinary zinc levels has been observed earlier in a varicty of neoplastic and traumatic disorders (6-9). A reversible increase in urinary zinc levels has been described in patients with tumours or after surgery (8) and in dogs after experimental injection of killed bacteria (10). A negative correlation of urinary zinc levels with serum zinc $(6,9)$

\footnotetext{
*Dr. Bohuslav Melichar from the Second Department of Internal Medicine, Charles University Medical School, Hradec Kralove, Czech Republic, was supported by a grant of the Austrian Ministry of Science and Research.

${ }^{\S}$ Author to whom correspondence should be addressed.
}

and a positive relationship to renal tubular dysfunction (7) were found in separate studies, but the cause and significance of the phenomenon remains unresolved. On the one hand, the tubular cell is important in renal zinc handling (11), on the other hand monocyte derived cytokines are known to affect tubular function (12).

HIV-1 infection is associated with a profound disturbance of cytokine networks, characterized by raised levels of e.g. interleukin-1 (IL-1), interleukin-6 (IL-6), tumour necrosis factor-(TNF-)- $\alpha$ (13-15), and interferon-(IFN)- $\gamma$ (16). Elevated IFN- $\gamma$ is reflected by increased serum and urinary neopterin which is widely used to monitor immune deterioration in HIV-1 infection $(17,18)$. The goal of the present study was to investigate a possible link between disturbed zinc metabolism and immune activation, estimated by urinary neopterin levels. 


\section{Materials and Methods}

Fifty-two patients, 38 males and 14 females, mean age 34.2 \pm 9.2 years (range 15-68 years) were examined. All were HIV-1 antibody seropositive (AbottELISA, Western blot). Among the male patients 18 were injecting drug users, 11 homosexual men, 5 men with haemophilia, and 4 acquired the infection probably through heterosexual contact. Among the female patients there were 8 injecting drug users. In 6 patients the infection was probably acquired via heterosexual contact. Patients were classified according to the Walter Reed (WR) staging system (19). Eighteen patients were treated with zidovudine and 3 with dideoxyinosine. At time of study, there were no other complications in patients except HIV1 infection. Two patients with WR6 received parenteral zinc supplementation and were therefore excluded from statistical evaluation. Seventeen healthy controls (12 males, 5 females) mean age $34.7 \pm 11.0$ years (range 20-57 years) served as controls. Patients and controls were not significantly different regarding age and body mass $(\mathrm{p}>0.1)$.

We obtained first morning urine sample from all of the studied subjects, as well as serum specimens of 25 patients and 14 controls. The concentration of zinc in the untreated and undiluted urine and serum specimens was determined by flame absorption spectrophotometry (Beckman 1233, Beckmann Instruments, Munich, Germany) at $213.9 \mathrm{~nm}$ wavelength $(7,20)$. Urine zinc concentration was divided by creatinine levels and expressed as zinc/creatinine ratio ( $\mathrm{mmol} \mathrm{Zn} / \mathrm{mol}$ creatinine) to take into account variations of urine density. Zinc clearance coefficient ( $\mathrm{ZCC} ; 1 / \mathrm{mol}$ creatinine) was calculated as the ratio of urine zinc/creatinine divided by serum zinc $(\mu \mathrm{mol} / 1)$.

Urinary neopterin and creatinine was measured by high performance liquid chromatography as described previously (21). Briefly, $100 \mu \mathrm{l}$ of the urine specimen were diluted in $1 \mathrm{ml}$ potassium phosphate buffer. Ten $\mu \mathrm{l}$ of the sample were injected into HPLC system (Varian LC 5500) and separated on C18 reversed phase column. Neopterin was quantified by its native fluorescence (353 $\mathrm{nm}$ excitation, $438 \mathrm{~nm}$ emission wavelengths), creatinine was simultaneously determined by ultraviolet absorbance at $235 \mathrm{~nm}$. Neopterin concentrations were expressed as neopterin/creatinine ratio. Statistical comparison between controls and patients was performed by Wilcoxon rank test, associations between variables were studied by Spearman rank correlation coefficient. For comparison of incidences, Fisher's exact test was employed. The determination of statistical significance was based on $\mathrm{p}<0.05$. level.

\section{Results}

Average serum zinc concentration in the HIV-1 infected individuals $(12.0 \pm 2.70 \mu \mathrm{mol} / 1)$ was significantly lower than in controls $(18.1+4.44 \mu \mathrm{mol} / \mathrm{l} ; \mathrm{U}=$ 4.02, $\left.\mathrm{p}=5.7 \times 10^{-5}\right)$. Urinary zinc levels in controls were $1.39 \pm 0.59 \mathrm{mmol} / \mathrm{mol}$ creatinine which is only slightly higher than reported for 24 hour sample (22). In patients with HIV-1 infection urinary zinc levels were $1.19 \pm 0.76 \mathrm{mmol} / \mathrm{mol}$ creatinine, which did not differ from controls $(p>0.05)$. There was no linear trend of urinary zinc levels when the patients were grouped according to stages. Serum zinc concentrations were lower in patients with HIV infection than in controls (Table 1). Serum zinc did not differ between WR-stages 1-4 compared to stages 5-6 (Table 1).

Urinary neopterin levels were found to be significantly higher in patients with HIV-1 infection than in controls $(663 \pm 589 \mu \mathrm{mol} / \mathrm{mol}$ creatinine vs. $117 \pm 24$ $\mu \mathrm{mol} / \mathrm{mol}$ creatinine; $\mathrm{U}=5.31 \mathrm{p}=1.1 \times 10^{-7}$ ). Urinary neopterin appeared to increase with progression of HIV-1 infection (Table 1), the difference between patients with WR1-4 and WR5 being however not significant $(\mathrm{p}>0.05)$.

Average ZCC did not differ between HIV-1 infected patients and controls. There was a gradual increase of average $\mathrm{ZCC}$ from controls to patients with WR1-4 and to patients with WR5-6 (Table 1). However, the difference between groups did not reach statistical significance because of large standard deviations. In the two patients with WR6, who received parenteral zinc supplementation $(60 \mu \mathrm{mol} /$ day $)$ and

Table 1. Serum $(\mu \mathrm{mol} / \mathrm{l})$ and urinary zinc levels $(\mathrm{mmol} / \mathrm{mol}$ creatinine), urinary neopterin concentrations $(\mu \mathrm{mol} / \mathrm{mol}$ creatinine) and zinc clearence coefficients (ZCC; $1 / \mathrm{mmol}$ creatinine) in patients with HIV-1 infection (mean value and S.D. of each group is shown).

\begin{tabular}{|c|c|c|c|c}
\hline WR-Stage & $\begin{array}{c}\text { Urinary } \\
\text { Neopterin }\end{array}$ & $\begin{array}{c}\text { Urinary } \\
\text { Zinc }\end{array}$ & $\begin{array}{c}\text { Serum } \\
\text { Zinc }\end{array}$ & ZCC \\
\hline Stage & $\begin{array}{c}n=30 \\
416 \pm 269\end{array}$ & $\begin{array}{c}n=30 \\
1.29 \pm 0.76\end{array}$ & $\begin{array}{c}n=14 \\
\mathrm{n}=4 \pm 1.69\end{array}$ & $\begin{array}{c}\mathrm{n}=14 \\
0.109 \pm 0.065\end{array}$ \\
\hline $5-6$ & $\begin{array}{c}\mathrm{n}=20 \\
1034 \pm 737\end{array}$ & $\begin{array}{c}\mathrm{n}=20 \\
1.05 \pm 0.78\end{array}$ & $\begin{array}{c}11.5 \pm 3.65 \\
\mathrm{n}=-11\end{array}$ & $\begin{array}{c}0.127 \pm 0.128 \\
\mathrm{n}=11\end{array}$ \\
\hline Controls & $\begin{array}{c}\mathrm{n}=17 \\
117 \pm 24^{*}\end{array}$ & $\begin{array}{c}1.39 \pm 0.59 \\
\mathrm{n}=17\end{array}$ & $\begin{array}{c}\mathrm{n}=14 \\
18.1 \pm 4.44^{*}\end{array}$ & $\begin{array}{c}0.082 \pm 0.038 \\
\mathrm{n}=14\end{array}$ \\
\hline
\end{tabular}

* significantly different from patients $(\mathrm{p}<0.0001)$; 

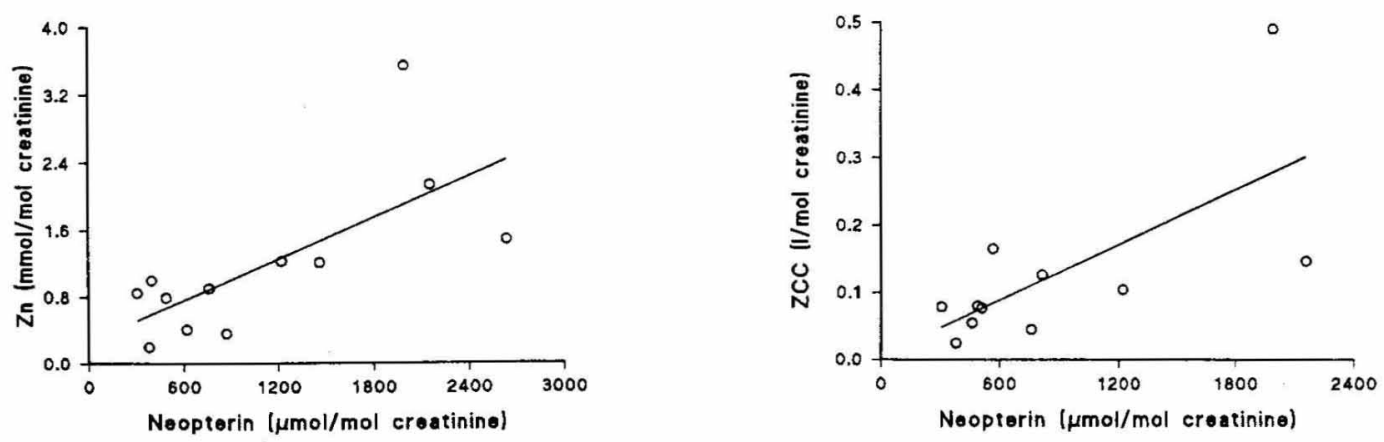

Fig.1: Correlation between urinary neopterin and zinc levels in WR6 patients (rs $=0.748, p<0.05$; left side) and between urinary xeopterin concentrations and zinc clearence coefficients (ZCC) in WR5-6 patients ( $\mathrm{ss}=0.673, \mathrm{p}\langle 0.05$; right side).

were consequently excluded from statistical evaluation, urinary zinc levels were high (3.69 and 2.14 $\mathrm{mmol} / \mathrm{mol}$ creatinine, respectively), although serum zinc value was low $(9.9 \mu \mathrm{mol} / \mathrm{l})$ in the patient with less pronounced urinary zinc excretion.

Positive correlations (Fig. 1) were found between urinary neopterin and urinary zinc levels in the 12 WR6 patients $(\mathrm{rs}=0.748, \mathrm{p}<0.05)$ and the $\mathrm{ZCC}$ in WR5-6 patients ( $r s=0.673, p>0.05$ ). There was no significant correlation between serum zinc and urinary neopterin and urinary zinc levels. Zinc concentrations did not differ between patients receiving or not receiving antiretroviral therapy.

\section{Discussion}

In agreement with previous reports, serum zinc was significantly lower in the patients with HIV-1 infection. Low serum zinc levels in late stage of HIV1 infection reflect chronic zinc deficiency. Under physiological conditions, zinc requirements are met by intestinal absorption (23), which may not be sufficient in HIV-1 infection when the small intestine is often affected and malabsorption is common (24). Decrease in serum zinc is a well characterized feature of the acute phase response and zinc metabolism is known to be influenced by monocyte-derived cytokines like IL-1, IL-6 and TNF- $\alpha$ (25-27). IL-6, a monocyte derived cytokine is known to induce liver'metallothionein synthesis, so that serum zinc levels fall. IL-1 and TNF- $\alpha$ have been reported to have a similar effect, probably through IL-6 release $(25,26)$. In addition, treatment with IFN- $\gamma$ was demonstrated to affect zinc metabolism (28). Increased neopterin levels in our patients indicate immune activation and endogenous formation of IFN- $\gamma$ (16, 17) and late stage HIV-1 infection is associated with high serum IFN- $\gamma$ levels (16). In our study, we found

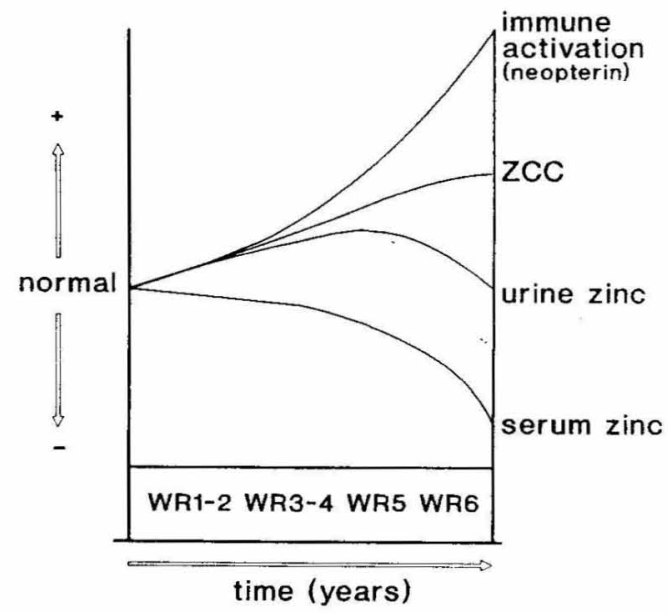

Figure 2. Simplified scheme of zinc metabolic changes together with immune activation in patients with HIV-1 infection: Immune activation in patients with HIV-1 infection: Immune activation increases throughout the course of disease (indicated by, e.g., neopterin levels) whereas scrum zinc levels decrease. Urinary excretion of zinc increases in early stages but starts to decrease in later stages when zinc deficiency becomes apparent, but zinc clearence coefficient (ZCC) remains to be high.

an association of neopterin with urinary zinc levels and $\mathrm{ZCC}$ in more advanced but not in early stages of HIV-1 infection.

Immune activation may reduce renal tubular reabsorption of zinc $(11,12)$. . However, urinary zinc levels were found to be increased only in a minority of patients, which confirms results of an earlier study (4). The absolute excretion values of urinary zinc depend on overall zinc status. Zinc deficiency particularly in late stages of HIV-1 infection may explain why urinary zinc levels are not elevated while $\mathrm{ZCC}$ corelates to the immune activation status in patients (Fig. 2). In agreement 2 patients receiving parenteral zinc, lost a significant part of the 
supplements in the urine and parenteral zinc administration did not prevent zinc deficiency. Reduced serum albumin concentrations in patients with HIV infection may explain why supplementation of $\mathrm{Zn}$ was not successful in the two patients (29) because serum $\mathrm{Zn}$ could not be sufficiently bound to albu$\min$.

The prognostic significance of decreased serum zinc (5) may be explained by the fact that cytokines involved in serum zinc changes also augment the replication of the virus (30). Our data show that neopterin levels are more closely associated to progression of HIV-1 infection than zinc levels. Serum zinc in the later stages of the disease appears to depend also on nutritional status. Probably due to this limitations, urinary zinc was not found to be of value in assessing HIV-1 infected patients. The clinical significance of zinc deficiency in HIV-1 infection remains uncertain. On the one hand, the decrease of zinc may be beneficial to patients withdrawing an essential nutrient from bacteria and tumour or virus-infected cells (31), on the other hand there are both, in vivo and in vitro data, showing zinc deficiency to be associated with dysregulated immune system functions (32-37).

A statistical correlation does not necessarily indicate any pathogenetic interaction mechanism. However, our data may indicate a link between immune activation and renal tubular function but only a prospective study could resolve a potential role of urinary loss to generate zinc deficiency.

\section{Acknowledgement}

This work was financially supported by the Austrian "Fonds zur Förderung Wissenschaftlicher Forschung, P9257”.

\section{References}

1. Caselli M. Biocchi R (1986) Taux seriques du zinc chez les malades atteints du syndrome dimmunodeficit acquir Presse Med 15: 1877.

2. Fabris N, Mocchegiani E, Galli M, Irato L. Lazzarin A Moroni M (1988) AIDS, zinc deficiency and thymic hormone failure. J Am Med Assoc 259: 839-840.

3. Shoemaker JD, Millard MC, Johnson PB (1988) Zinc in human immmunodeficiency virus infection. $\mathrm{J} \mathrm{Am} \mathrm{Med}$ Assoc 260: 1881-1882.

4. Walter RM, Oster MH, Lee TJ, Flynn N, Keen CL (1990) Zinc status in human immunodeficiency virus infection. Life Sci 46: 1597-1600.

5. Graham NMH, Sorensen D. Odaka N, Brookmeyer R. Chan D, Willett WC, Morris JS. Saah AJ (1991) Relation- ship of serum copper and zinc levels to HIV-I seropositivity and progression to AIDS. J Acquir Immune Defic Syndr 4: 976-980.

6. Voyatzoglou V. Mountokalakis T, Tsata-Voyatzoglou V. Koutselinis A. Skalkeas G (1982) Serum zinc levels and urinary zinc excretion in patients with bronchogenic carcinoma. Am J Surg 144: 355-358.

7. Boosalis MG, Solem LD, Cerra FB, Konstantinides F, Ahrenholz DH. McCall JT, McClain CJ (1991) Increased urinary zinc excretion after thermal injury. $\mathrm{J}$ Lab Clin Med 118: $538-545$.

8. Mountokalakis T, Voyatzoglou V, Boukis D, Tsata-Voyatzoglou V. Koutselinis A. Merikas G. (1980) Differential effect of surgical injury and thermal burn on zinc metabolism in man. Klin Wochenschr 58: 695-697.

9. Allen JI, Bell E, Boosalis MG, Oken MM, McClain CJ. Levine AS, Morley JE (1985) Association between urinary zinc excretion and lymphocyte dysfunction in patients with lung cancer. Am J Med 79: 209-215.

10. Klaiman AP, Victery W, Kluger MJ. Vander AJ (1981) Urinary excretion of zinc and iron following acute injection of dead bacteria in dog. Proc Soc Exp Biol Med 167: 165-171.

11. Yuzbasiyan-Gurkan VA, Brewer GJ, Vander AJ. Guenther MJ, Prasas AS (1989) Net renal tubular reabsorption of zinc in healthy man and impaired handling in sickle cell anemia. Am J Hematol 31: 87-90.

12. Schreiner GF, Kohan DE (1990) Regulation of renal transport processes and hemodynamics by macrophages and lymphocytes. Am J Physiol 258: F761-F767.

13. Breen EC, Rezai AR, Nakajima K. Beall GN, Mitsuyasu RT. Hirano T, Kishimoto T, Martinez-Maza O (1990) Infection with HIV is associated with elevated IL-6 levels and production. J Immunol 144: 480-485.

14. Laehdevirta J, Maury CPJ, Teppo AM, Repo H (1988) Eleva-ted levels of ciculating cachectin/tumor necrosis factor in patients with acquired immunodeficiency syndrome. Am J Med 85: 289-291.

15. Gallo P, Frei K, Rordorf C. Lazdis J. Tavolato B, Fontana A (1989) Human immunodeficiency virus type 1 (HIV-1) infection of the central nervous system: an evaluation of cytokines in cerebrospinal fluid. J Neuroimmunol 23: 109116.

16. Fuchs D, Hausen A, Reibnegger G, Werner EW, WernerFelmayer G, Dierich MP, Wachter H (1989) Interferon-gamma concentrations are increased in sera from individuals with human immunodeficiency virus type 1. J Acquir Immune Defic Syndr 2: 158-162.

17. Fuchs D, Hausen A, Reibnegger G, Werner ER, Dierich MP. Wachter H (1988) Neopterin as a marker for activated cell-mediated immunity: application in HIV infection. Immunol Today 9: 150-155.

18. Bogner JR, Matuschke A. Heinrich B, Eberle E. Goebel FD (1988) Serum neopterin levels as predictor of AIDS. Klin Wochenschr 66: 1015-1018.

19. Redfield RR. Wright DC. Tramont EC (1986) The Walter Reed Staging Classification for HTLV-III/LAV infection. $\mathrm{N}$ Engl J Med 314: 131-132.

20. Melichar B, Zeimet A, Artner-Dworzak E. Schröcksnadel H, Marth C, Wachter H, Fuchs D (1993) Association between increased urinary zine and neopterin concentrations in women with gynaecological cancer. Tumordiagn Ther 


\section{4: $110-112$.}

21. Wachter H, Fuchs D, Hausen A, Reibnegger G, Werner ER (1989) Neopterin as marker for activation of cellular immunity: immunologic basis and clinical application. Adv Clin Chem 27: 81-141.

22. Killerich S, Christensen MS, Naestoft J, Christiansen C (1980) Determination of zinc in serum and urine by atomic absorption spectrophotometry: Relationship between serum levels of zinc and proteins in 104 normal subjects. Clin Chim Acta 105: 231-239.

23. Cousins RJ (1985) Absorption, transport. and hepatic metabolism of copper and zinc: Special reference to metallothionein and ceruloplasmin. Physiol Rev 65: 238-309.

24. Kotler DP, Gaetz HP, Lange M, Klein EB, Holt PR (1984) Enteropathy associated with the acquired immunodeficiency syndrome. Ann Intern Med 101: 421-428.

25. Morimoto A, Sakata Y, Watanabe T, Murakami N (1989) Characteristics of fever and acute-phase response induced in rabbits by IL-I and TNF. Am J Physiol 256: R35-R41.

26. Schroeder JJ, Cousins RJ (1990) Interleukin 6 regulates metallothionein gene expression and zinc metabolism in hepatocyte monolayer cultures. Proc Natl Acad Sci (USA) 87: 3137-3141.

27. Dinarello CA (1989) Interleukin-1 and its biologically related cytokines. Adv Immunol 44: 153-205.

28. Morimoto A, Murakami N, Tafada M, Teshirogi S, Watanabe $\mathrm{T}$ (1987) Fever and acute phase response induced in rabbits by human recombinant interferon-gamma. $\mathbf{J}$ Physiol 391: 209-218.
29. Heise W, Nehm K, L'Age M. Averdunk R, G ther T (1989) Concentrations of magnesium, zinc and copper in serum of patients with acquired immunodeficinecy syndrome. J Clin Chem Clin Biochem 27: 515-517.

30. Poli G, Fauci AS (1992) The effect of cytokines and pharmacologic agents on chronic HIV infection. AIDS Res Human Retroviruses 8: 191-197.

31. DeWys W, Pories WJ, Richter MC, Strain WH (1970) Inhibition of Walker 256 carcinoma growth by dietary zinc deficiency. Proc Soc Exp Biol Med 135: 17-22.

32. Allen JI, Kay NE. McClain CJ (1981) Severe zinc deficiency in humans: Association with a reversible T-lymphocyte dysfunction. Ann Intern Med 95: 154-157.

33. Harrer T, Wolf B, N er W, Schwarz W, Bergner D, Kalden JR (1992) In vitro activation of peripheral mononuclear cells by zinc in HIV-infected patients and healthy controls. Clin Exp Immunol 89: 285-289.

34. Falutz J, Tsoukas C, Gold P (1988) Zinc as a cofactor in human immunodeficiency virus-induced immunosuppression. J Am Med Assoc 259: 2850-2851.

35. Miller GG, Strittmatter WJ (1992) Identification of human T cells that recquire zinc for growth. Scand J Immunol 36: $269-277$.

36. Tanaka, Y, Shiozawa S, Morimoto I, Fujita T (1990) Role of zinc in interleukin 2-mediated T-cell activation. Scand J Immunol 31:547-552.

37. Miller GG. Strittmatter WJ (1992) Identification of human $\mathrm{T}$ cells that require zinc for growth. Scand $\mathrm{J}$ Immunol 36: $269-277$. 